\title{
PENERAPAN PSAK NO. 45 TENTANG PELAPORAN KEUANGAN ORGANISASI NIRLABA PADA SANGGAR SENI BUDAYA LOGOS MA'KANTAR
}

\author{
Oleh: \\ Claudia W.M. Korompis \\ email: wanda_korompis@yahoo.co.id
}

\begin{abstract}
ABSTRAK
Perkembangan ekonomi global tak lepas dari peranan organiasi-organisasi profit maupun non profit. Organisasi non profit (nirlaba) menjadi wadah yang menjadikan sumber daya manusia sebagai aset yang paling berharga. Walaupun tidak terkonsentrasi pada profit, namun pelaporan keuangan yang disajikan oleh organisasi ini haruslah memiliki suatu standar sebagai dasar penyusunan dan pelaporan bagi pihak yang berkepentingan. PSAK No. 45 menyatakan bahwa organisasi nirlaba memperoleh sumber daya dari sumbangan para anggota dan para penyumbang lain yang tidak mengharapkan imbalan apapun dari organisasi tersebut. Tujuan laporan keuangan untuk pihak internal adalah untuk mengetahui situasi keuangan yang ada dalam organisasi tersebut, sedangkan untuk pihak eksternal bertujuan untuk mengetahui apakah dana yang ada telah dipergunakan dengan baik dan terlampir dalam laporan keuangan organisasi tersebut. Penelitian dilakukan di Sanggar Seni Budaya Logos Ma'kantar. Penelitian ini bertujuan untuk melihat bagaimana penyusunan laporan keuangan Sanggar Seni Budaya Logos Makantar apakah telah sesuai dengan PSAK No 45.Metode analisis yang digunakan adalah metode kualitatif deskriptif sifatnya menguraikan, menggambarkan, membandingkan suatu data.Hasil dan kesimpulan dari penelitian ini adalah laporan keuangan Sanggar Seni Budaya Logos Makantar belum menyusun laporan keuangan sesuai dengan format laporan keuangan nirlaba yang ada dalam Pernyataan Standar Akuntansi No. 45, dan hal ini membuat pengurus terpacu untuk segera menerapkan laporan keuangan sesuai dengan PSAK No. 45 untuk kepentingan organisasi kedepan.
\end{abstract}

Kata kunci: psak no. 45, nirlaba

\section{ABSTRACT}

Global economic development could not be separated from the role of an organization of profit and non-profit organizations. Non-profit organizations (non-profit) into a container made of human resources as the most valuable asset. Although it is not concentrated on profits, but the financial reporting presented by this organization must have a standard as a basis for the preparation and reporting to interested parties. SFAS No. 45 states that nonprofit organizations to obtain resources from the donations of members and other contributors do not expect any compensation from the organization. The objective of financial statements for internal parties is to know the financial situation that exists in the organization, while external parties aimed to determine whether the available funds have been used properly and in the attached financial statements of the organization. The study was conducted at the Cultural Arts Studio Logos Ma'kantar. This study aims to look at how the financial statements Cultural Arts Studio Logos Makantar whether in accordance with SFAS No. 45.Metode analysis used is descriptive qualitative method outlines the nature, describing, comparing a data.Hasil and conclusions of this study are the financial statements of Studio Art culture Logos Makantar not prepare financial statements in accordance with the format of the financial statements of a non-profit that exists in SFAS No. 45, and this makes the board are encouraged to immediately apply the financial statements in accordance with SFAS No. 45 for the benefit of the organization in the future.

Keywords: sfas no.45, nonprofit 


\section{Latar Belakang Penelitian}

\section{PENDAHULUAN}

Pertumbuhan ekonomi ditandai dengan pesatnya pertumbuhan organisasi-organisasi profit maupun nonprofit. Organisasi-organisasi nonprofit (nirlaba) meliputi organisasi keagamaan, rumah sakit, sekolah negeri, organisasi jasa sukarelawan, maupun organisasi budaya.

Karakteristik organisasi nirlaba berbeda dengan organisasi bisnis. Perbedaan utama yang mendasar terletak pada cara organisasi nirlaba memperoleh sumber daya yang dibutuhkan untuk melakukan berbagai aktivitas operasinya. Organisasi nirlaba memperoleh sumber daya dari sumbangan para anggota dan para penyumbang lain yang tidak mengharapkan imbalan apapun dari organisasi tersebut. Sebagai akibat dari karakteristik tersebut, dalam organisasi nirlaba timbul transaksi tertentu yang jarang atau bahkan tidak pernah terjadi dalam organisasi bisnis misalnya penerimaan sumbangan. (Hendrawan, 2011)

Penyusunan laporan keuangan harus jelas untuk pelaporan bagi pihak yang memberikan sumbangan. Laporan Keuangan secara umum bertujuan untuk memberikan informasi tentang posisi keuangan, kinerja, dan arus kas perusahaan yang bermanfaat bagi sebagian besar kalangan pengguna laporan dalam rangka membuat keputusan-keputusan ekonomi serta menunjukkan pertanggungjawaban (stewardship) manajemen atas penggunaan sumber-sumber daya yang dipercayakan kepada mereka.Laporan keuangan setidaknya disajikan secara tahunan dan harus menyajikan secara wajar posisi keuangan, kinerja keuangan, perubahan ekuitas, dan arus kas. Laporan keuangan pada organisasi nirlaba terdiri atas neraca, laporan laba rugi, laporan perubahan ekuitas, laporan arus kas dan catatan atas laporan keuangan.(IAI, 2012)

Manajemen organisasi nirlaba harus mempertanggungjawabkan sumbangan atau dana yang telah diterima dari berbagai pihak berupa laporan keuangan. PSAK No.45 mengungkapkan bahwa organisasi nirlaba memperoleh sumber daya dari sumbangan para anggota dan para penyumbang lain yang tidak mengharapkan imbalan apapun dari organisasi tersebut. Tujuan laporan keuangan untuk pihak internal adalah untuk mengetahui situasi keuangan yang ada dalam organisasi tersebut, sedangkan untuk pihak eksternal bertujuan untuk mengetahui apakah dana yang ada telah dipergunakan dengan baik dan terlampir dalam laporan keuangan organisasi tersebut. (Cintokowati, 2010)

Sanggar seni budaya Logos Ma'kantar didirikan pada tanggal 11 Februari 2013. Sanggar ini adalah organisasi non pemerintah yang berdiri sendiri dan tidak berada di bawah instansi pemerintah namun memiliki korelasi dengan lembaga pemerintahan dalam mensosialisasikan seni budaya itu sendiri yang dalam hal ini pemerintah kotamadya Manado dan pemerintah provinsi Sulawesi Utara. Sanggar ini menjadi wadah bagi para seniman tradisional Sulawesi Utara guna pelestarian budaya. Sanggar ini sendiri menerima bantuan dana dari pihak pemerintah untuk kegiatan sosialisasi budaya. Sanggar ini berdiri kurang lebih 1 tahun, oleh karena itu perlu dilihat bagaimana penyusunan laporan keuangan sanggar seni budaya Logos Makantar apakah telah sesuai dengan PSAK No.45, dan jika belum diterapkan perlu diarahkan untuk penyusunan laporan keuangan yang benar.

Berdasarkan uraian di atas penulis tertarik untuk melakukan penelitian dengan judul :“

PENERAPAN PSAK NO. 45 TENTANG PELAPORAN KEUANGAN ORGANISASI NIRLABA PADA SANGGAR SENI BUDAYA LOGOS MA'KANTAR.”

\section{Tujuan Penelitian}

Tujuan penelitian ini adalah untuk melihat bagaimana penerapan laporan keuangan sanggar seni budaya Logos Makantar apakah telah sesuai dengan apa yang tercantum dalam Pernyataan Standar Akuntansi Keuangan (PSAK) Nomor 45. 


\section{Organisasi Nirlaba}

\section{TINJAUAN PUSTAKA}

Organisasi nirlaba atau organisasi non profit adalah suatu organisasi yang bersasaran pokok untuk mendukung suatu isu atau perihal di dalam menarik perhatian publik untuk suatu tujuan yang tidak komersil, tanpa ada perhatian terhadap hal-hal yang bersifat mencari laba (moneter).Organisasi nirlaba meliputi gereja, sekolah negeri, derma publik, rumah sakit dan klinik publik, organisasi politis, bantuan masyarakat dalam hal perundang-undangan, organisasi jasa sukarelawan, serikat buruh, asosiasi profesional, institute, riset, museum, dan beberapa para petugas pemerintah.

Organisasi nirlaba memiliki ciri-ciri sebagai berikut :

1. Sumber daya entitas. Sumber daya entitas berasal dari para penyumbang yang tidak mengharapkan pembayaran kembali atau manfaat ekonomi yang sebanding dengan jumlahsumber daya yang diberikan.

2. Menghasilkan barang/jasa tanpa bertujuan menumpuk laba. Menghasilkan barang/jasa tanpa bertujuan menumpuk laba, kalau suatu entitas menghasilkan laba, maka jumlahnya tidak pernah dibagikan kepada para atau pemilik entitas tersebut.

3. Tidak ada kepemilikan seperti lazimnya pada organisasi bisnis. Tidak ada kepemilikan seperti lazimnya pada organisasi bisnis, dalam arti bahwa kepemilikan dalam organisasi nirlaba tidak dapat dijual, dialihkan atau ditebus kembali atau kepemilikan tersebut tidak mencerminkan proporsi pembagian sumber daya entitas pada suatu likuidasi atau pembubaran entitas. (Hasana, 2011)

\section{Tujuan Laporan Keuangan}

Tujuan utama pelaporan keuangan adalah menyediakan informasi yang bermanfaat untuk membuat keputusan investasi atau pemberian pinjaman (Horngren dan Harrison, 2007 : 9).

Mardiasmo (2009: 167) menyatakan bahwa tujuan laporan keuangan organisasi nirlaba dalam SFAC 4 tersebut adalah sebagai berikut.

1. Laporan keuangan organisasi nonbisnis hendaknya dapat memberikan informasi yang bermanfaat bagi penyedia dan calon penyedia sumber daya, serta pemakai dan calon pemakai lainnya dalam pembuatan keputusan yang rasional mengenai alokasi sumber daya organisasi.

2. Memberikan informasi untuk membantu para penyedia dan calon penyedia sumber daya, serta pemakai dan calon pemakai lainnya dalam menilai pelayanan yang diberikan oleh organisasi nonbisnis serta kemampuannya untuk melanjutkan memberi pelayanan tersebut.

3. Memberikan informasi yang bermanfaat bagi penyedia dan calon penyedia sumber daya, serta pemakai dan calon pemakai lainnya dalam menilai kinerja manajer organisasi nonbisnis atas pelaksanaan tanggung jawab pengelolaan serta aspek kinerja lainnya.

4. Memberikan informasi mengenai sumber daya ekonomi, kewajiban, data kekayaan bersih organisasi, serta pengaruh dari transaksi, peristiwa dari kejadian ekonomi yang mengubah sumber daya dan kepentingan sumber daya tersebut.

5. Memberikan informasi mengenai kinerja organisasi selama satu periode. Pengukuran secara periodik atas perubahan jumlah dan keadaan/kondisi sumber kekayaan bersih organisasi nonbisnis serta informasi mengenai usaha dan hasil pelayanan organisasi secara bersama-sama yang dapat menunjukkan informasi yang berguna untuk menilai kinerja.

6. Memberikan informasi mengenai bagaimana organisasi memperoleh dan membelanjakan kas atau sumber daya kas, mengenai utang dan pembayaran kembali utang, dan mengenai faktor-faktor lain yang dapat mempengaruhi likuiditas organisasi. 
7. Memberikan penjelasan dan interpretasi untuk membantu pemakai dalam memahami informasi keuangan yang diberikan.

\section{Unsur-Unsur Laporan Keuangan Organisasi Nirlaba}

Akuntansi organisasi nirlaba meliputi bentuk laporan keuangan dan nama-nama rekening berdasarkan pola PSAK No.45. Unsur-unsur laporan keuangan berdasarkan PSAK No.45.

a. Laporan posisi keuangan

Laporan posisi keuangan merupakan nama lain dari neraca pada laporan keuangan lembaga komersial. Laporan ini memberikan informasi mengenai besarnya aset atau harta lembaga dan sumber perolehan aset tadi (bisa dari hutang atau dari aktiva bersih) pada satu titik tertentu.

b. Laporan aktivitas

Laporan aktivitas berisi dua bagian besar yaitu besaran pendapatan dan biaya lembaga selama satu periode anggaran. Pendapatan digolongkan berdasarkan restriksi atau ikatan yang ada. Sedangkan beban atau biaya disajikan dalam laporan aktivitas berdasarkan kriteria fungsional, dengan demikian beban biaya akan terdiri dari biaya kelompok program jasa utama dan aktivitas pendukung.

c. Laporan arus kas

Laporan arus kas menunjukkan arus uang kas masuk dan keluar untuk suatu periode. Periode yang dimaksud adalah periode sama dengan yang digunakan oleh laporan aktivitas. Penyajian arus kas masuk dan keluar harus digolongkan ke dalam tiga kategori yaitu sebagai berikut.

1) Aktivitas Operasi

Dalam kelompok ini adalah penambahan dan pengurangan arus kas yang terjadi pada perkiraan yang terkait dengan operasional lembaga. Contoh yang mempengaruhi arus kas operasi adalah sebagai berikut.

a) Surplus atau defisit lembaga (datanya diambil dari laporan aktivitas).

b) Depresiasi atau penyusutan (karena depresiasi dianggap sebagai biaya, namun tidak terjadi uang kas keluar) setiap tahun.

c) Perubahan pada account piutang lembaga.

d) Account (perkiraan buku besar) lain seperti: persediaan, biaya dibayar di muka dan lain-lain.

2) Aktivitas Investasi

Termasuk dalam perkiraan ini adalah semua penerimaan dan pengeluaran uang kas yang terkait dengan investasi lembaga. Investasi dapat berupa pembelian/penjualan aktiva tetap, penempatan/pencairan dana deposito atau investasi lain. Beberapa contoh arus kas yang berasal dari aktivitas investasi adalah :

a) Pembayaran kas untuk membeli aset tetap, aset tidak berwujud, dan aset jangka panjangl ain, termasuk biaya pengembangan yang dikapitalisasi dan aset tetap yang dibangun sendiri;

b) Penerimaan kas dari penjualan tanah, bangunan, dan peralatan, serta asset tidak berwujud dan asset jangka panjang lain.

3) Aktivitas Pendanaan

Termasuk dalam kelompok ini adalah perkiraan yang terkait dengan transaksi berupa penciptaan atau pelunasan kewajiban hutang lembaga dan kenaikan/penurunan aktiva bersih dari surplus-defisit lembaga.

Transaksi lain yang mengakibatkan perubahan arus kas masuk dan keluar dalam kelompok ini adalah sebagai berikut. 
a) Penerimaan kas dari penyumbang yang penggunaannya dibatasi untuk jangka panjang.

b) Penerimaan kas dari sumbangan dan penghasilan investasi yang penggunaannya dibatasi untuk perolehan, pembangunan dan pemeliharaan aktiva tetap atau peningkatan dana abadi.

c) Bunga, deviden yang dibatasi penggunaannya untuk jangka panjang.

d. Catatan atas laporan keuangan

Catatan atas laporan keuangan, merupakan bagian yang tidak terpisah dari laporan-laporan di atas. Tujuan pemberian catatan ini agar seluruh informasi keuangan yang dianggap perlu untuk diketahui pembacanya sudah diungkapkan.

Catatan atas laporan keuangan dapat berupa:

1) Perincian dari suatu perkiraan yang disajikan, misalnya aktiva tetap;

2) Kebijakan akuntansi yang dilakukan, misalnya metode penyusutan serta tarif yang digunakan untuk aktiva tetap lembaga, metode pencatatan piutang yang tidak dapat ditagih serta presentase yang digunakan untuk pencadangannya. (IAI, 2012)

\section{Penelitian Terdahulu}

Pontoh (2013) melakukan penelitian dengan judul penerapan laporan keuangan organisasi nirlaba berdasarkan PSAK No 45. Hasil yang didapat Gereja Bukit Zaitun belum menerapkan penyusunan laporan keuangan sesuai dengan PSAK No. 45. Persamaan dengan penelitian ini adalah menggunakan penelitian kualitatif deskriptif, perbedaan terletak pada objek yang digunakan dimana peneliti sebelumnya mengambil objek penelitian adalah Gereja, sedangkan peneliti mengambil objek sanggar seni budaya.

\section{Jenis Penelitian}

\section{METODE PENELITIAN}

Jenis penelitian yang digunakan dalam penelitian ini adalah penelitian kualitatif deskriptif yaitu metode yang sifatnya menguraikan, menggambarkan, membandingkan suatu data dan keadaan serta menerangkan suatu keadaan sedemikian rupa sehingga dapatlah ditarik suatu kesimpulan.

\section{Metode Pengumpulan Data}

Data yang digunakan adalah laporan keuangan dari Sanggar Seni Budaya Logos Ma'kantar juga hasil wawancara dan pengamatan di objek tersebut.

Teknik pengumpulan data yang digunakan sebagai berikut :

1. Wawancara (Interview), yaitu teknik pengumpulan data yang dilakukan dan diperoleh dengan mengadakan Tanya jawab langsung dengan bagian-bagian yang berkepentingan dan terlibat langsung dengan masalah yang dibahas dalam penelitian ini.

2. Observasi, dimana peneliti akan melakukan pengamatan langsung ke objek penelitian untuk mendapatkan dan mencatat data-data yang diperlukan.

3. Dokumentasi dimana penelitian ini dimaksudkan untuk mendapatkan data yang dimaksud baik teori dan laporan yang ada di objek yang diteliti.

\section{Gambaran Umum Objek Penelitian}

\section{HASIL PENELITIAN DAN PEMBAHASAN}

Sanggar seni budaya "Logos Ma'Kantar" adalah organisasi non pemerintah yang berdiri sendiri dan tidak berada di bawah instansi pemerintah namun memiliki korelasi dengan lembaga pemerintahan dalam mensosialisasikan seni budaya itu sendiri yang dalam hal ini pemerintah kotamadya Manado dan pemerintah provinsi Sulawesi Utara. Sanggar seni Budaya Logos Ma'kantar awalnya sudah terbentuk pada Maret 2012 dan melaksanakan kegiatan secara mandiri dengan pembiayaan bersama dari pengurus, pembina dan anggota. 
Mengingat pentingnya pelestarian budaya dan keinginan untuk lebih berkembang maka sanggar ini akhirnya memiliki akta pendirian nomor : 76 tanggal 07 Maret 2013, dengan Rapat Umum pembentukan badan Pembina, badan pengurus dan penetapan sanggar pada 11 Februari 2013. Sanggar seni budaya "Logos Ma'Kantar" berdomisili di Perumahan Bumi Kilu Permai Lingkungan II Kelurahan Paniki Satu Kecamatan Mapanget Kota Manado. Kegiatan-kegiatan seni budaya Sulut yang pernah diikuti seperti Pengisi Acara beberapa kegiatan kerohanian seperti Ibadah acara besar Gereja, Hari Raya Paskah, Hari Raya Natal, dan Pengucapan syukur di Wilayah Kota Manado.

Visi dan misi "Sanggar Seni Budaya Logos Ma'Kantar"

Visi : "Pelestarian Seni Budaya dan Adat Sulawesi Utara"

Misi : 1. Menjadikan Seni Budaya Sulawesi Utara sebagai Identitas diri dan alat untuk memperkokoh kesatuan dan persatuan Bangsa Indonesia berdasarkan Pancasila dan Undang-Undang Dasar Negara Republik Indonesia.

2. Pemberdayaan potensi-potensi seni budaya sebagai nilai luhur kebudayaan Sulawesi Utara.

3. Pelestarian dan pengembangan kreatifitas karya seni dan budaya melalui penanaman rasa cinta dari generasi muda terhadap kebudayaan daerah sendiri.

Struktur organisasi Sanggar seni budaya "Logos Ma'Kantar" adalah sebagai berikut.

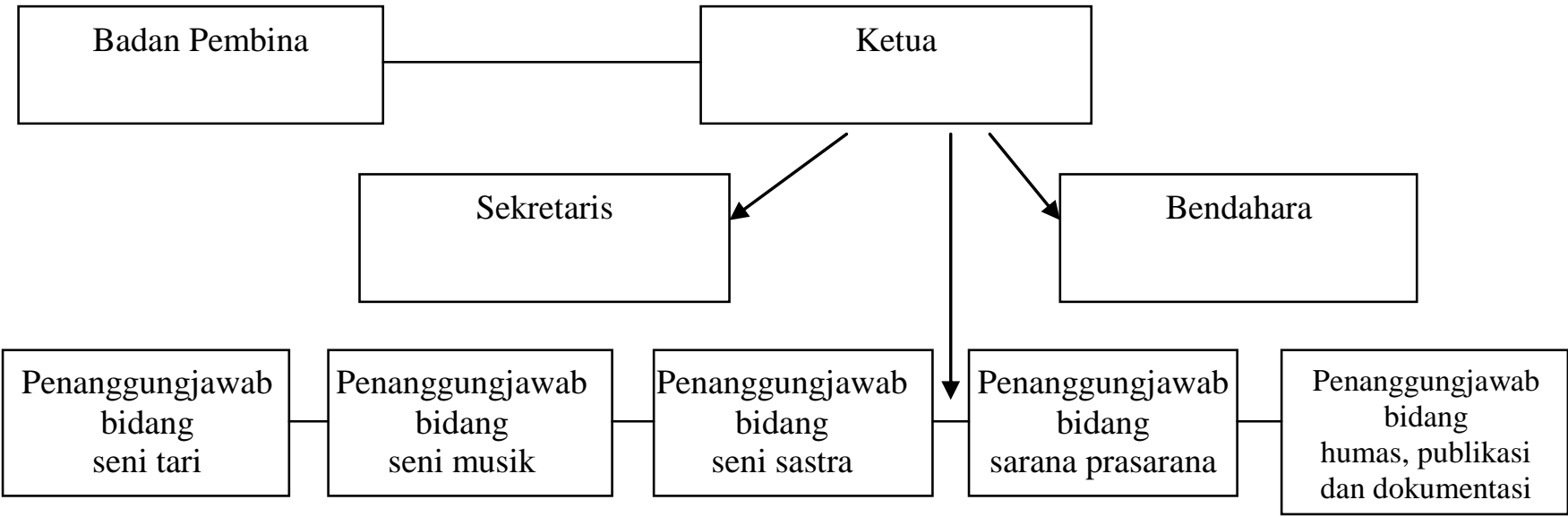

Gambar 1. Struktur Organisasi

Sumber : Sanggar seni budaya "Logos Ma'Kantar"

\section{Hasil Penelitian}

\section{Sistem Pelaporan Keuangan Sanggar seni budaya "Logos Ma'Kantar"}

Berdasarkan AD/ART sanggar seni budaya "Logos Ma'Kantar" pada Bab V Pasal 8 disebutkan bahwa : Sumber dana yang diperoleh antara lain dari Instansi Pemerintah , Sumbangan swasta yang tidak mengikat, Hibah perorangan yang tidak mengikat, Penjualan jasa atas hak kekayaan intlektual atau paten yang dimiliki sanggar, Penjualan hak kekayaan intelektual atau hak cipta atas karya ciptaan yang telah dibuat sanggar, Iuran pengurus/anggota dan juga (arisan anggota serta simpan-pinjam, kalau ada), dan sebagainya. Belanja kegiatan diatur sepenuhnya oleh bendahara dengan mengacu kepada keputusan yang telah disepakati bersama dan telah disahkan oleh sanggar. Lingkup belanja kegiatan adalah belanja yang memenuhi kebutuhan dalam hal ini proses pembinaan, pelatihan dan pembuatan karya cipta seni yang dianggarkan secara tepat dan spesifik oleh pengurus. Pengeluaran dana sepenuhnya difilterisasi oleh ketua bekerjasama dengan bendahara dan prosedur agar biaya yang dikeluarkan sesuai dengan berapa besar yang dibutuhkan selama proses karya cipta seni yang dikerjakan. Penggalian sumber dana dapat dilakukan oleh pengurus apabila telah disetujui oleh ketua sanggar. Pelaporan dana yang diterima harus aktual dan spesifik. 
Penggalian sumber dana tidak dapat dilakukan secara individu tanpa adanya koordinasi dan legalisasi dari perangkat-perangkat sanggar lainnya termasuk pengurus.

Laporan pertanggungjawaban yaitu laporan pengurus dalam hal ini ketua kepada semua perangkat organisasi. Laporan pertanggungjawaban sekurang-kurangnya memuat keterangan berkenaan dengan pelaksanaan kegiatan yang dilakukan dan pengeluaran dana beserta lampiran yang mengatkan pengeluaran dana tersebut jika diperlukan. Laporan pertanggungjawaban akan diarsipkan secara lengkap oleh sekretaris untuk kemudian menjadi salah satu dokumen yang dianggap penting dalam organisasi.

\section{Pembahasan}

Penyajian Laporan Arus Kas menurut PSAK No. 45

Tabel 1. Laporan Arus Kas Sanggar Seni Budaya Logos Ma'Kantar

\begin{tabular}{|c|c|}
\hline $\begin{array}{c}\text { Sanggar Seni Budaya Logos Ma'Kantar } \\
\text { Laporan Arus Kas } \\
\text { 31 Desember } 2013\end{array}$ & \\
\hline Arus Kas dari Aktivitas Operasi : & \\
\hline Kas dari penyumbang & Rp. 149.986 .750 \\
\hline Pembayaran: & \\
\hline Perlengkapan & Rp. $\quad 2.260 .500$ \\
\hline Kas bersih yang diterima (digunakan) untuk aktivitas operasi & Rp. 147.726.250 \\
\hline Arus Kas dari Aktivitas Investasi : & \\
\hline Pembelian Peralatan & (p. 147.223.750) \\
\hline Kas bersih yang diterima (digunakan) untuk aktivitas Investasi & (Rp. 147.223.750) \\
\hline Arus Kas dari Aktivitas Pendanaan : & \\
\hline Investasi awal & Rp. $\quad 1.000 .000$ \\
\hline Kas bersih yang diterima (digunakan) untuk aktivitas Pendanaan & (Rp. $\quad 1.000 .000)$ \\
\hline Kenaikan (penurunan) bersih dalam kas dan setara kas & Rp. $\quad 1.502 .500$ \\
\hline Kas dan setara kas pada awal tahun & Rp. \\
\hline Kas dan setara kas pada akhir tahun & $\mathbf{1 . 5 0 2 . 5 0 0}$ \\
\hline
\end{tabular}

Sumber : Logos Ma'Kantar

Penyajian Laporan Posisi Keuangan menurut PSAK No. 45 Sanggar Seni Budaya Logos Ma'Kantar

Tabel 2. Laporan Posisi Keuangan Sanggar Seni Budaya Logos Ma'Kantar

\begin{tabular}{|c|c|c|}
\hline & $\begin{array}{c}\text { Sanggar Seni Budaya Logos Ma'Kantar } \\
\text { Laporan Posisi Keuangan } \\
\text { 31 Desember } 2013\end{array}$ & \\
\hline \multicolumn{3}{|c|}{ 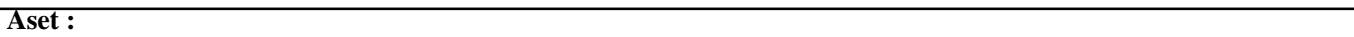 } \\
\hline Kas dan setara Kas & & Rp. $\quad 1.502 .500$ \\
\hline Perlengkapan & & Rp. $\quad 2.260 .500$ \\
\hline Peralatan & & Rp. 147.223 .750 \\
\hline Jumlah Aset & & Rp. 150.986 .750 \\
\hline \multicolumn{3}{|l|}{ Kewajiban dan Ekuitas } \\
\hline Kewajiban & & - \\
\hline Ekuitas & & Rp. 150.986 .750 \\
\hline Jumlah Kewajiban dan ekuitas & & Rp. 150.986 .750 \\
\hline
\end{tabular}

Sumber : Logos Ma'Kantar

Penyajian Catatan Atas Laporan Keuangan menurut PSAK No. 45

Tabel 3. Catatan Atas Laporan Keuangan Sanggar Seni Budaya Logos Ma'Kantar

Sanggar Seni Budaya Logos Ma'Kantar
Catatan atas Laporan Keuangan
Catatan:
sanggar seni budaya Logos Ma'kantar melakukan invetasi awal Rp.1.000.000 dimana Rp.900.000 merupakan uang kas dan
Rp.100.000 merupakan bank. Setelah investasi awal sanggar seni budaya Logos Ma'kantar menerima sumbangan (bansos) senilai
Rp.149.986.750 yang dicatat sebagai kas masuk dari penyumbang (Bansos).

Sumber : Logos Ma'Kantar 


\section{Penerapan Laporan Posisi Keuangan menurut PSAK No. 45 pada Sanggar Seni Budaya Logos Ma'Kantar}

a. Aset

Kas dan setara kas yang disajikan dalam laporan posisi keuangan merupakan total atau jumlah dari aset bersih pada akhir tahun. Aset untuk Sanggar Seni Budaya Logos Ma'Kantar hanya terdiri dari kas dan setara kas, perlengkapan dan peralatan sanggar. Peralatan dan perlengkapan Sanggar Seni Budaya Logos Ma'Kantar laporannya berupa jumlah unit yang disusun dalam daftar inventaris.

b. Kewajiban dan Aset Bersih

Sanggar Seni Budaya Logos Ma'Kantar tidak memiliki saldo kewajiban pada akhir tahun. Nilai saldo Modal adalah nilai investasi awal ditambah dengan sumbangan.

\section{Penerapan Laporan Arus Kas menurut PSAK No. 45 pada Sanggar Seni Budaya Logos Ma'Kantar}

a. Arus Kas dari Aktivitas Operasi

Akun-akun yang disajikan adalah penambahan dan pengurangan arus kas yang terjadi pada perkiraan yang terkait dengan operasional Sanggar Seni Budaya Logos Ma'Kantar seperti Kas dari penyumbang dan perlengkapan.

b. Arus Kas dari Aktivitas Investasi

Yang termasuk dalam perkiraan ini adalah semua penerimaan dan pengeluaran uang kas yang terkait dengan investasi untuk pembelian peralatan penunjang kegiatan.Untuk tahun 2013 hanya terjadi pengeluaran dari investasi, dan tidak ada penerimaan.

c. Arus Kas dari Aktivitas Pendanaan

Perkiraan yang termasuk dalam aktivitas pendanaan adalah perkiraan penerimaan dari kontribusi pengurus yang penggunaanya dibatasi.

\section{Penerapan Catatan Atas Laporan Keuangan menurut PSAK No. 45 pada Sanggar Seni Budaya Logos Ma'Kantar}

Catatan atas Laporan Keuangan Sanggar Seni Budaya Logos Ma'Kantar berupa :

a. Catatan atas nilai kas pada tahun 2013 dan sumbernya.

\section{Kesimpulan}

\section{PENUTUP}

Berdasarkan hasil penelitian dan pembahasan makadiperoleh beberapa kesimpulan sebagai berikut.

1. Sanggar Seni Budaya Logos Ma'Kantar belum menerapkan sepenuhnya laporan keuangan yang sesuai dengan format laporan keuangan organisasi nirlaba yang ada dalam Pernyataan Standar Akuntansi No. 45 karena belum ada penyajian laporan aktivitas.

2. Walaupun tidak mengikuti format laporan keuangan yang ditetapkan oleh Ikatan Akuntan Indonesia, namun secara umum tujuan penyusunan laporan keuangan pada Sanggar Seni Budaya Logos Ma'Kantar telah tercapai.

\section{Saran}

Saran yang dapat diberikan dalam penerapan penyusunan laporan keuangan pada Sanggar Seni Budaya Logos Ma'Kantar sebagai berikut.

1. Penyusunan Laporan Keuangan sebaiknya berpedoman dan mengikuti ketentuan yang telah ditetapkan oleh Ikatan Akuntan Indonesia yang tertuang dalam Pernyataan Standar Akuntansi Keuangan Nomor 45 agar informasi yang disajikan dalam laporan keuangan lebih jelas, relevan dan memiliki daya banding yang tinggi, selain itu juga agar tujuan dari penyusunan laporan keuangan dapat tercapai dengan maksimal. 
2. Pengurus Sanggar Seni Budaya Logos Ma'Kantar harus melakukan penyajian atas laporan aktivitas.

3. Bagi Badan Pengurus Sanggar Seni Budaya Logos Ma'Kantar perlu mengetahui tentang pelaporan keuangan organisasi nirlaba sesuai dengan PSAK No 45dengan cara melakukan pelatihan.

\section{DAFTAR PUSTAKA}

Cintokowati, Chindi. 2010. Akuntansi Masjid vs Gereja, Organisasi Nirlaba. http://cintokowati.blogspot.com/2010/11/asp-akuntansi-masjid-vs-gereja.html Tanggal akses 14 November 2010

Hasana, Kharisty. 2011. Ciri-Ciri Organisasi Nirlaba, Organisasi Nirlaba. http://kharistyhasanah.blogspot.com/2011/10/organisasi-nirlaba.html Tanggal akses 07 Oktober 2011

Hendrawan, Rony. 2011. Analisis Penerapan PSAK No. 45 Tentang Pelaporan Keuangan Organisasi Nirlaba Pada Rumah Sakit Berstatus Badan Layanan Umum. Skripsi. Fakultas Ekonomi Universitas Diponegoro. Semarang.

Horngren, Charles T., Harrison, Walter T. 2007. Akuntansi. Erlangga. Jakarta.

Ikatan Akuntan Indonesia (IAI). 2012. Standar Akuntansi Keuangan. Salemba Empat. Jakarta.

Mardiasmo. 2009. Akuntansi Sektor Publik. Edisi Empat. ANDI. Yogyakarta.

Pontoh, Chenly Ribka. 2013. Penerapan Laporan Keuangan Organisasi Nirlaba Berdasarkan Psak No 45 pada Gereja Bzl. Jurnal Emba. Unsrat. Manado. 